\title{
Habitat Modeling of the Black-Legged Tick: Reducing the Risk of Lyme disease at a Military Installation in the United States
}

\author{
Thomas M Kollars* \\ Health Sciences, Liberty University, Lynchburg, Virginia, USA \\ Submission: February 08, 2018; Published: February 16, 2018 \\ *Corresponding author: Thomas Martin Kollars, Health Sciences, Liberty University, Lynchburg, USA, Email: tkollars@liberty.edu
}

\begin{abstract}
The black-legged tick (Ixodes scapularis) is the principal vector of Lyme borreliosis in the eastern United States. Military personnel and their family members, working and living on military installations are at risk of Lyme borreliosis where this tick species occurs. A study was conducted to determine which habitat variables determined distribution and density of the black-legged tick at the Edgewood Area, Aberdeen Proving Ground, Maryland, USA. Shrub density was found to be a significant predictor of the distribution and density of the black-legged tick at the Edgewood Area with higher resolution than previous published predicted models of the black-legged tick $\left(1 \mathrm{~m}^{2} \mathrm{p}<0.001\right)$. At the Edgewood Area, the enlisted personnel family housing area was adjacent to a high risk area. With good communication and inter-agency cooperation integrated vector management can be use to prioritize areas to have tick reduction. This information can be used by public health leadership at Edgewood to be proactive and reduce the risk for Lyme borreliosis and other tick-borne diseases to military personnel and their families.
\end{abstract}

Keywords: Borrelia, Ixodes; Acari; Epidemiology; Geographic Information System

\section{Introduction}

Borrelia burgorferi is the etiologic agent of Lyme borreliosis, also known as Lyme disease. Lyme borreliosis is found in Asia, Europe and the USA, primarily in forested habitats [1]. Lyme disease is transmitted through the bite of an infected tick, most often in the genus Ixodes. Immature black-legged ticks (I. scapularis) are usually infected with $B$. burgdorferi when they feeding on a warm-blooded vertebrate, such as deer mice, Peromyscus species. Once engorged with a blood meal, the infected tick will drop off, molt to the next stage, quest for a new host, then feed upon and infect another host, including humans. Lyme borreliosis has a significant impact on public health in the United States. According the Centers for Disease Control and Prevention, about 30,000 cases are reported annually, with reports of cases in Maryland among the top 10\% [2]. In addition to B. burgdorferi, the blacklegged tick is also a vector of Anaplasma phagocytophilum (human granulocytic anaplasmosis), Babesia microti (babesiosis), and Borrelia miyamotoi (a relapsing fever Borrelia), and deer tick virus.

Military personnel and their families can be at risk from vector-borne diseases at military installations. For example, high risk areas for Yersinia pestis, the etiologic agent of bubonic plague, were identified at the United States Air Force Academy installation, with some high risk sites adjacent to family housing on the base [4]. Lyme borreliosis poses a significant risk to military personnel and their families. In 2015, over 1,000 ticks tested by the Army Public Health Command, were positive for B. burgdorferi; $21 \%$ of I. scapularis ticks were positive and all $I$. pacificus ticks were negative [5]. Because of the importance of I. scapularis in the transmission of Lyme diseases, the present study was conducted to identify factors affecting the distribution and density of this tick species at the Edgewood Area military installation, Aberdeen Proving Ground, Maryland.

\section{Methods and Results}

There are approximately 1,000 people living on Edgewood Area, Aberdeen Proving Ground, with nearly 15,000 people working both areas of Aberdeen Proving Ground. Nearly 20,000 retirees and their families use the recreational facilities at Edgewood [6]. Data from 300 sample points was collected from oak forest, pine forest, and ecotone. Ticks ( $\mathrm{N}=344)$ were collected using a one-meter square cloth tick drag, at $10 \mathrm{~m}$ intervals. Trees were counted by transect using a $2 \mathrm{~m}$ pole; shrub, fern, monocot, and dicot plant density were estimated using a $4 \mathrm{~m}$ plastic square. Data was analyzed using Statistica software and ArcGIS. Shrub density was provided the best predictive variable with high resolution, $\mathrm{p}<0.001$ at $1 \mathrm{~m}^{2}$ (Table 1 ). Density and distribution of black-legged ticks varied geographically (Figure 1). 


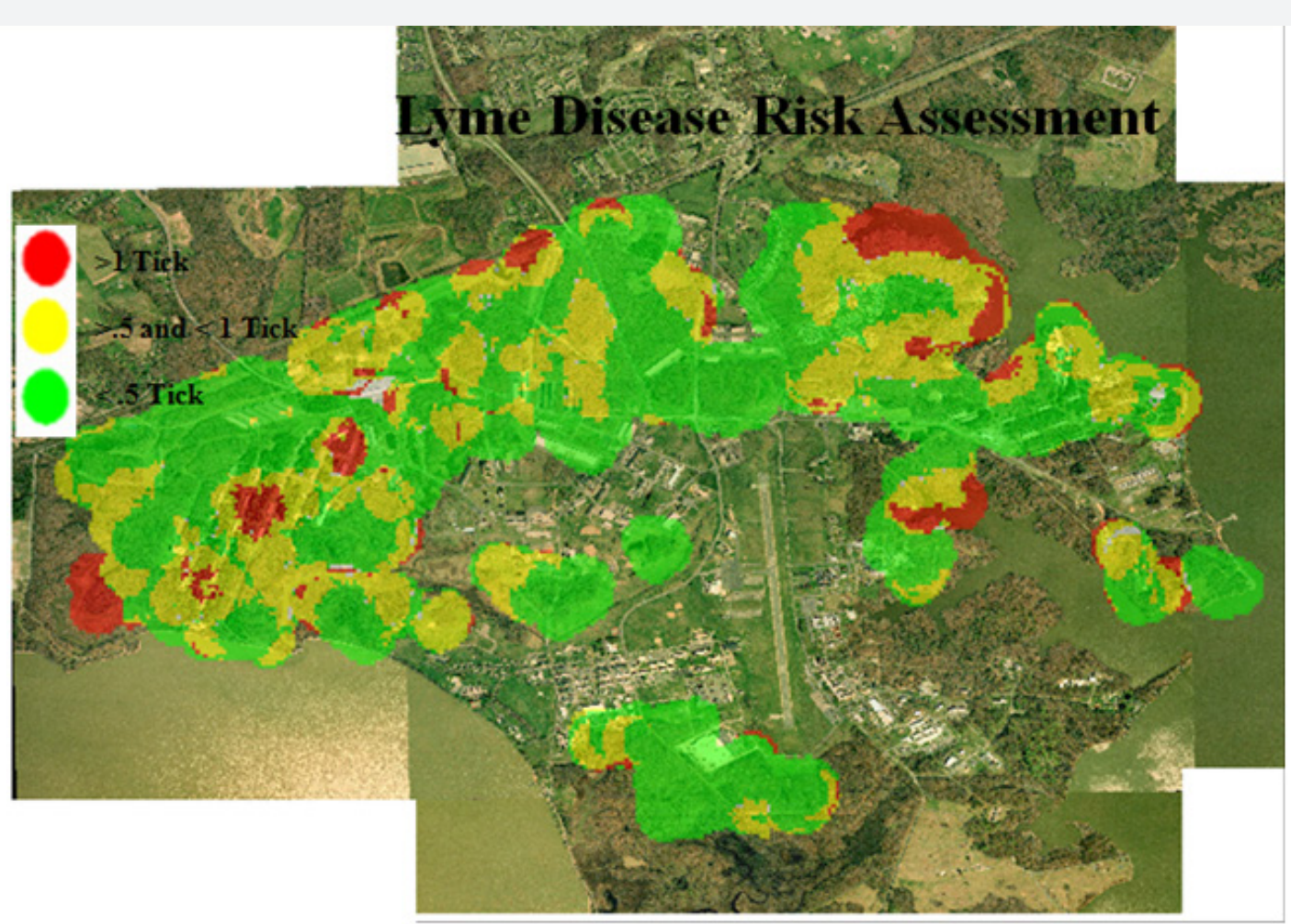

Figure 1: Risk Assessment of Lyme borreliosis based on predicted distribution of the black-legged tick (Ixodes scapularis) per square meter at Edgewood Area, Aberdeen Proving Ground.

Table 1: Regression summary for the number of black-legged ticks (Ixodes scapularis) and abiotic and biotic variables; $\mathrm{R}=0.97, \mathrm{R} 2=0.93$ $F(11.8)=10.18, p<0.05$, SE Estimate: 0.77 , significant factors yellow highlight.

\begin{tabular}{|c|c|c|}
\hline Intercept & Beta & p-level \\
\hline Elevation & -2.11 & 0.22 \\
\hline Habitat Type & 0.04 & 0.77 \\
\hline Percent Canopy & 0.21 & 0.12 \\
\hline Tree Density & -0.05 & 0.75 \\
\hline Shrub Density & 0.89 & 0.001 \\
\hline Monocot Density & -0.35 & 0.84 \\
\hline Dicot Density & $0 . .3$ & 0.82 \\
\hline Fern Density & -0.04 & 0.78 \\
\hline
\end{tabular}

\section{Discussion}

Several abiotic and biotic factors influence the distribution and density of $I$. scapularis, e.g. precipitation, elevation, host composition, and vegetative land cover [7,8]. In the present study, density of shrubs was identified as the most important factor of the variables studied for determining presence and density of the black-legged tick. The model also provided higher resolution with higher predictability than other published models of $I$. scapularis. For example, a predictive model for I. scapularis had a resolution of $30 \mathrm{~m}^{2}$ when using land cover data [8].

Demographic factors can also play a role in determining risk of becoming infected with vector-borne diseases. For example, poor and minority neighborhoods can be at higher risk of West Nile virus [9]. Military officers and enlisted personnel often live at different housing areas on military installations and they and their families. Housing areas on military bases may differ in the risk from Lyme borreliosis. At Edgewood, officer quarters are located in the southwest and enlisted quarters are located in the northeast. In a previous study at the Edgewood Area, enlisted family housing appeared to be at higher risk of West Nile virus than officer family housing due to variation in abiotic and biotic between sites [10]. Further investigations to determine risk vector-borne diseases based on geographic and demographic factors on military installations is suggested.

Military public health officials should incorporate peridomestic tick surveillance as part of the installation integrated vector management plan. The black-legged tick is often found in peridomestic habitats where Lyme borreliosis is highly endemic [3]. Additional investigation into demographic, social and behavioral factors and the risk of Lyme borreliosis at military installations should be investigated. Leadership from public health officials is required for any successful IVM efforts, however this leadership is not always provided. As an example, previous leadership at Edgewood Area were informed that the enlisted personnel housing area was adjacent to a high 
risk area for Lyme disease and recommendations for control methods were suggested. Unfortunately, at that time, no plan of action was taken to reduce the risk of Lyme borreliosis to the military personnel and their families living near the high risk area. The justification provided by the former leadership, was the department did not have good working relationship with the agency having the responsibility for vector control. The information provided in this model can assist public health leadership at Edgewood, by being proactive with the objective of reducing the risk for Lyme borreliosis and other tick-borne diseases to military personnel and their families. Identifying the risk of vector-borne diseases and implementing integrated vector management at Edgewood and other military installations is of significant public health value. Once the risk of an infectious disease is determined, medical and preventive measures can be taken to reduce the threat to military personnel and their families.

\section{Acknowledgement}

The views expressed in this publication are those of the authors and do not reflect the official policy of the United States Government. We appreciate the logistical support provided by the Consequence Management Unit and the Centers for Health Promotion and Preventive Medicine. This paper is dedicated to the memory of Peggy Kollars, wife of Tom and mother of five. Peggy dedicated her life to improving the life of others through research in vector-borne diseases and in spreading the Gospel. She shared her passion for biology and life students at university and high school levels. She is missed by her loved ones and friends but we know we'll see her again because we have faith in Jesus too.

\section{References}

1. http://www.who.int/ith/diseases/lyme/en/

2. https://www.cdc.gov/lyme/stats/humancases.html

3. Feldman KA, Connally NP, Hojgaard A, Jones EH, White JL, et al. (2015) Abundance and infection rates of Ixodes scapularis nymphs collected from residential properties in Lyme disease-endemic areas of Connecticut, Maryland, and New York. J Vect Ecol 40: 198-201.

4. Kollars TM, Kollars E, and Kollars PG (2017) United States Air Force Academy: Identifying areas at risk for the persistence of plague using the Bioagent Transport and Environmental Modeling System (BioTEMS). J Micro Mod Tech 3: 1-3.

5. Army Public Health Center (2015) Army Vector-Borne Disease Report.

6. Agency for Toxic Substances and Disease Registry (2008) Public health assessment U.S. Army Aberdeen Proving Ground, Edgewood Area Aberdeen, Harford County, Maryland, USA.

7. Johnson TL, Bjork JK, Neitzel DF, Dorr FM, Schiffman EK, et al. (2016) Habitat Suitability Model for the Distribution of Ixodes scapularis (Acari: Ixodidae) in Minnesota. Journal of medical entomology 53(3): 598606.

8. Kollars TM, Oliver JH, Kollars PG, Durden LA (1999) Seasonal activity and host associations of Ixodes scapularis (Acari: Ixodidae) in southeastern Missouri. J Med Entomol 36: 720-726.

9. LaDeau SL, Leisnham PT, Biehler D, and Bodner D (2013) Higher Mosquito Production in Low-Income Neighborhoods of Baltimore and Washington, DC: Understanding Ecological Drivers and MosquitoBorne Disease Risk in Temperate Cities. Int J Env Res Pub Hlth; 10: 1505-1526.

10. Kollars TM (2018) Modeling Risk and Prevention of West Nile Virus at a Military Installation. Int J Dent Med Sci (in press).

\begin{tabular}{l} 
Your next submission with Juniper Publishers \\
will reach you the below assets \\
- Quality Editorial service \\
- Swift Peer Review \\
- Reprints availability \\
- E-prints Service \\
- Manuscript Podcast for convenient understanding \\
- Global attainment for your research \\
- Manuscript accessibility in different formats \\
( Pdf, E-pub, Full Text, Audio) \\
- Unceasing customer service \\
Track the below URL for one-step submission \\
https://juniperpublishers.com/online-submission.php \\
\hline
\end{tabular}

